\title{
Long-Term Plasticity in the Regulation of Olfactory Bulb Activity by Centrifugal Fibers from Piriform Cortex
}

\author{
Joy L. Cauthron and Jeffrey S. Stripling \\ Department of Psychological Science, University of Arkansas, Fayetteville, Arkansas 72701
}

\begin{abstract}
Olfactory bulb granule cells are activated synaptically via two main pathways. Mitral/tufted (M/T) cells form dendrodendritic synapses on granule cells that can be activated by antidromic stimulation of the lateral olfactory tract (LOT). Centrifugal fibers originating from the association fiber (AF) system in piriform cortex (PC) make axodendritic synapses on granule cells within the granule cell layer (GCL) that can be activated by orthodromic stimulation of AF axons in the PC. We explored functional plasticity in the AF pathway by recording extracellularly from individual $\mathrm{M} / \mathrm{T}$ cells and presumed granule cells in male Long-Evans rats under urethane anesthesia while testing their response to LOT and AF stimulation. Presumed granule cells driven synaptically by LOT stimulation (type L cells) were concentrated in the superficial half of the GCL and were activated at short latencies, whereas those driven synaptically by AF stimulation (type A cells) were concentrated in the deep half of the GCL and were activated at longer latencies. Type A cells were readily detected only in animals in which the AF input to the GCL had been previously potentiated by repeated high-frequency stimulation. An additional bout of highfrequency stimulation administered under urethane caused an immediate increase in the number of action potentials evoked in type A cells by AF test stimulation and a concomitant increase in inhibition of $\mathrm{M} / \mathrm{T}$ cells. These results underscore the importance of the role played in olfactory processing by $\mathrm{PC}$ regulation of $\mathrm{OB}$ activity and document the long-lasting potentiation of that regulation by repeated high-frequency AF activation.
\end{abstract}

Key words: granule cell; mitral cell; tufted cell; olfactory bulb; piriform cortex; potentiation

\section{Introduction}

A wealth of anatomical and physiological evidence indicates that olfactory bulb $(\mathrm{OB})$ granule cells play a critical role in the processing of olfactory information (Mori, 1987; Shepherd et al., 2004). Granule cells are activated by mitral/tufted (M/T) cells and in turn inhibit those cells via reciprocal dendrodendritic synapses, thus sculpting patterns of neural activity within the $\mathrm{OB}$ and regulating its output (Mori, 1987; Scott et al., 1993; Shipley and Ennis, 1996; Shepherd et al., 2004). The other major source of synaptic input to granule cells comes from centrifugal fibers to the OB that originate primarily in olfactory cortex (Davis and Macrides, 1981; Luskin and Price, 1983; Carson, 1984; Shipley and Adamek, 1984), allowing granule cells to participate not only in the initial processing of incoming sensory information, but also in central regulation of that processing.

The centrifugal input to OB granule cells from olfactory cortex has been the subject of relatively little functional analysis due in part to the difficulty of selectively activating these axons. Stim-

Received April 1, 2014; revised June 5, 2014; accepted June 10, 2014.

Author contributions: J.L.C. and J.S.S. designed research; J.L.C. and J.S.S. performed research; J.L.C. and J.S.S. analyzed data; J.L.C. and J.S.S. wrote the paper.

This work was supported by the National Institute on Deafness and Other Communication Disorders (Grant R01-DC02271 to J.S.S.) and by the Marie Wilson Howells Fund.

Correspondence should be addressed to Jeffrey S. Stripling, Department of Psychological Science, 216 Memorial Hall, University of Arkansas, Fayetteville, AR 72701. E-mail: jstripli@uark.edu.

J.L. Cauthron's present address: Department of Behavioral Sciences, University of West Alabama, Livingston, AL 35470 .

DOI:10.1523/JNEUROSCI.1314-14.2014

Copyright $\odot 2014$ the authors $\quad 0270-6474 / 14 / 349677-11 \$ 15.00 / 0$ ulation of these centrifugal fibers evokes a negative wave in the local field potential recorded in the granule cell layer (GCL) that represents a population EPSP in granule cells (Nakashima et al., 1978; Laaris et al., 2007; Boyd et al., 2012). Several forms of plasticity have been documented at the synapses made by centrifugal fibers on granule cells, including paired-pulse potentiation (Balu et al., 2007) and synaptic potentiation, which typically lasted as long as recordings were maintained (20-180 min in different studies; Gao and Strowbridge, 2009; Manabe et al., 2011; Ma et al., 2012). Because these studies used acute preparations, they were unable to determine whether functional plasticity in this circuit persisted beyond this limited time span.

Using awake freely moving rats we have previously demonstrated that high-frequency stimulation of association fibers $(\mathrm{AFs})$ in the piriform cortex (PC), which consist of the axons of PC pyramidal cells, produces a long-lasting potentiation of local field potentials evoked in the $\mathrm{OB}$ and $\mathrm{PC}$ by AF stimulation (Stripling and Patneau, 1999). A similar potentiation can be produced by direct stimulation of the GCL in the OB (Stripling et al., 1988, 1991). This potentiation has important properties that can be studied only in chronic preparations, including its gradual development requiring several daily bouts of high-frequency stimulation to reach its maximum amplitude and its persistence in latent form long after its apparent decay, permitting its full reinstatement by a single bout of high-frequency stimulation delivered after an $8 \mathrm{~d}$ delay (Stripling and Galupo, 2008). The present research explored the functional impact of this potentiation in the $\mathrm{OB}$ by recording from $\mathrm{M} / \mathrm{T}$ cells and presumed granule 
cells under urethane anesthesia while selectively stimulating the AF in both naive rats and rats that had previously undergone potentiation of the AF input to the OB. Our results demonstrate that AF stimulation selectively activates presumed granule cells in the deep portion of the GCL, resulting in inhibition of $\mathrm{M} / \mathrm{T}$ cells, and that both of these effects undergo long-lasting potentiation after repeated high-frequency AF stimulation.

\section{Materials and Methods}

Animals

Subjects were adult male Long-Evans rats (Harlan Laboratories) weighing 370-470 g and housed individually under a $12 \mathrm{~h} / 12 \mathrm{~h}$ light/dark cycle, with all data collected during the light phase. All procedures were performed in accordance with the National Research Council's Guide for the Care and Use of Laboratory Animals and were approved by the University of Arkansas Institutional Animal Care and Use Committee.

\section{Overview of experimental design}

Animals were chronically implanted with a recording electrode in the GCL of the $\mathrm{OB}$ and with stimulating electrodes in the $\mathrm{PC}$ that could selectively activate either AF or lateral olfactory tract (LOT) axons (Fig. 1 $A, B$ ). After recovery from surgery, animals were assigned to one of two conditions: naive or potentiated. Naive animals received no further treatment in the next phase of the experiment, whereas potentiated animals received high-frequency AF stimulation at daily intervals to induce substantial potentiation of the population EPSP evoked in the GCL by AF stimulation. Animals in both conditions were then anesthetized with urethane and extracellular recordings were made from $\mathrm{M} / \mathrm{T}$ cells and presumed granule cells. Peristimulus time histograms were constructed to assess each cell's response to singlepulse AF and LOT stimulation both before and after a single bout of high-frequency AF stimulation that fully reinstated potentiation in the potentiated group. Although the response of cells to AF stimulation was the primary focus of the study, the response to LOT stimulation was also monitored as a control for nonspecific changes in cell excitability. In a separate set of animals, $\mathrm{AF}$ axons projecting to the $\mathrm{OB}$ from the $\mathrm{PC}$ were activated antidromically from the

$\mathrm{OB}$ to determine whether their conduction times were compatible with the long latencies at which the effects of AF stimulation on M/T cell and presumed granule cell activity occurred.

\section{Electrode implantation surgery}

Chronic stimulating and recording electrodes were implanted stereotaxically using a flat-skull orientation (Paxinos and Watson, 1997) under sodium pentobarbital (42.5 mg/kg, i.p.) and chloral hydrate $(100 \mathrm{mg} / \mathrm{kg}$, i.p.) anesthesia, with atropine sulfate $(0.5 \mathrm{mg} / \mathrm{kg}$, i.p.) administered to reduce respiratory congestion. Electrodes were constructed of untwisted polyimide-coated type 316 stainless steel wire (California Fine Wire) joined with Epoxylite 6001-M varnish. A monopolar, 100- $\mu \mathrm{m}$-diameter electrode for recording local field potentials was implanted in the core of the GCL in the OB $(8.7 \mathrm{~mm}$ anterior to bregma, $1.2 \mathrm{~mm}$ lateral to the

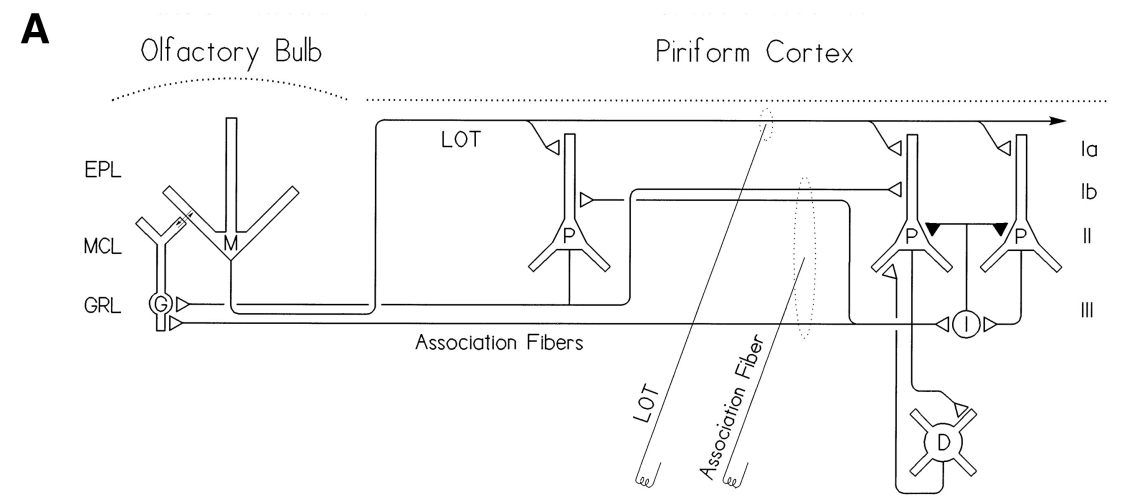

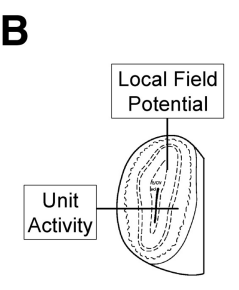

OB Recording

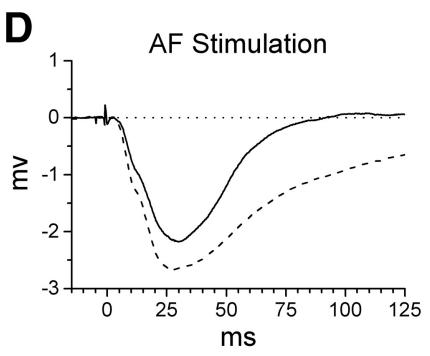

Stimulation
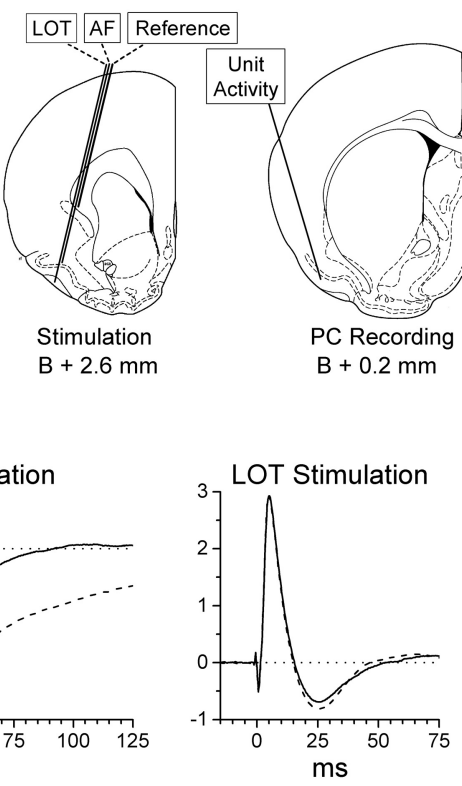

$\mathrm{B}+2.6 \mathrm{~mm}$
C

E

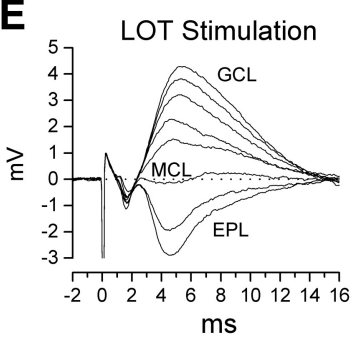

Figure 1. Olfactory forebrain circuitry and evoked responses. $A$, Simplified diagram of $O B$ and $P C$ circuitry depicting the stimulating sites used in the present experiment. The dotted ellipse around each electrode tip indicates the axons targeted for activation by stimulation through that electrode. Cell layers shown include the external plexiform layer (EPL), MCL, and GCL in the $0 B$, and layers la, Ib, II, and III in the PC. Cell types are indicated as follows: M, mitral cell; G, granule cell; P, pyramidal cell; I, inhibitory interneuron; $D$, deep multipolar cells in layer III and the endopiriform nucleus. $\boldsymbol{B}$, Location of stimulating and recording electrodes. Fine wire electrodes used for stimulation and for recording of local field potentials were chronically implanted at the beginning of the study. Microelectrodes used for recording extracellular unit activity were advanced into the $\mathrm{OB}$ or $\mathrm{PC}$ during the recording sessing trajectories that avoided the chronic electrode assembly on the dorsal surface of the skull. Diagrams of coronal sections are derived from Paxinos and Watson (1997), with permission. C, Example of an M/T cell identified by antidromic activation of the LOT (four consecutive sweeps). D, Examples of local field potentials evoked under urethane anesthesia in the GCL of the a potentiation treatment. Each trace is an average of 12 evoked responses. $\boldsymbol{E}$, Example of a depth profile used to determine the location of the MCL. Local field potentials evoked by LOT stimulation were recorded as a microelectrode was advanced in $50 \mu \mathrm{m}$ steps along the tract shown in $\boldsymbol{B}$. Each trace is the average of 24 evoked responses.

midline, and $1.6 \mathrm{~mm}$ below the dura). Electrical stimulation was accomplished via a tripolar electrode consisting of two $85-\mu$ m-diameter stimulation leads targeted for the AF and LOT, with the AF lead located $1 \mathrm{~mm}$ dorsal to the LOT lead, and a $125-\mu \mathrm{m}$-diameter stimulation reference lead scraped bare for $2.5 \mathrm{~mm}$ with its tip located $3 \mathrm{~mm}$ dorsal to the LOT lead. This electrode was lowered at a $14^{\circ}$ lateral angle through a burr hole over the anterior PC (2.6 $\mathrm{mm}$ anterior to bregma and $1.6 \mathrm{~mm}$ lateral to the midline) using electrophysiological guidance (Stripling and Patneau, 1999) to place the deepest lead in the LOT, resulting in placement of the second lead in the AF in shallow layer III of the PC (Fig. 1B). Reference and ground leads for monopolar recording from the GCL electrode were provided by stainless steel screws over the contralateral anterior neocortex and ipsilateral posterior neocortex, respectively. Animals were allowed a minimum of $7 \mathrm{~d}$ postoperative recovery before testing began. 


\section{Selective activation of AF versus $L O T$ axons}

All stimulation of AF or LOT axons consisted of 0.1 ms cathodal squarewave constant-current pulses delivered through either the AF or LOT lead of the stimulation electrode. Because these two fiber systems run adjacent to each other in the anterior PC, we monitored the selectivity of our stimulation via the local field potential evoked at the recording electrode in the GCL (Fig. 1D). LOT stimulation evokes a large positive wave in the GCL representing a population EPSP produced in granule cells by dendrodendritic synapses in the EPL (Rall and Shepherd, 1968; Mori, 1987), whereas AF stimulation evokes a late negative wave representing a population EPSP produced in granule cells by the synapses of centrifugal fibers in the GCL (Nakashima et al., 1978; Laaris et al., 2007). In the present study, the current intensity for all AF stimulation was limited to a value that was $\leq 85 \%$ of the threshold for activation of the LOT-evoked population EPSP, thereby ensuring selective activation of AF axons. In contrast to AF stimulation, selective activation of the LOT is difficult to verify because even focal LOT stimulation evokes a late negative wave that can be difficult to distinguish from that evoked by AF stimulation (Fig. $1 D$ ). In the present study, we limited activation of extra-LOT fibers via the LOT electrode by setting the current intensity for LOT stimulation to evoke a population EPSP that was $\leq 85 \%$ of its maximum amplitude.

\section{Induction of potentiation in awake animals}

After recovery from electrode implantation surgery, each animal in the potentiated condition received repeated high-frequency AF stimulation to produce potentiation of the population EPSP evoked in the GCL by this fiber system. High-frequency AF stimulation consisted of $3010-$ pulse $100 \mathrm{~Hz}$ trains delivered at $5 \mathrm{~s}$ intervals through the $\mathrm{AF}$ electrode using a current intensity that was $85 \%$ of the threshold for LOT activation with a ceiling of $200 \mu \mathrm{A}$. This stimulation (referred to hereafter as a potentiation treatment) was repeated once daily until the level of potentiation reached a plateau $(6.8 \pm 2.2 \mathrm{~d}$; mean $\pm \mathrm{SD})$. Testing under urethane was conducted $1-2 \mathrm{~d}$ after the last waking potentiation treatment.

\section{Unit recording under urethane anesthesia}

The effect of AF and LOT stimulation on OB unit activity was examined in both naive and potentiated animals under urethane anesthesia (1.4 $\mathrm{g} / \mathrm{kg}$, i.p.). The anesthetized animal was placed in a stereotaxic instrument, the cisterna magna drained, the lateral surface of the OB exposed, the dura and arachnoid layers removed, and the surface of the OB covered with warm $1.5 \%$ agar in physiological saline. Throughout the recording procedure, core body temperature was monitored by a rectal probe and maintained at $37^{\circ} \mathrm{C}$ by a thermostatically controlled heating pad and respiratory rate was monitored via a thermocouple placed at the opening of the contralateral naris. Unit activity was recorded using either metal microelectrodes or glass micropipettes pulled using a Sutter P-97 horizontal puller. Microelectrodes were advanced horizontally into the lateral surface of the $\mathrm{OB}$ near its midpoint in both the anterior-posterior and dorsal-ventral dimensions (Fig. 1B) using a Burleigh Inchworm piezoelectric micromanipulator that provided a precise readout of the position of each recorded cell along the microelectrode tract. Extracellular action potentials were amplified using an Molecular Devices Axoprobe $1 \mathrm{~A}$ amplifier and Cyberamp 380 signal conditioner at a band pass of $300-10,000 \mathrm{~Hz}$ and were digitized for subsequent analysis. AF- and LOT-evoked local field potentials from both the microelectrode and the chronic recording electrode in the GCL were amplified at a band pass of $0.1-6000 \mathrm{~Hz}$ and also digitized for later analysis.

Every microelectrode penetration extended from the lateral surface of the OB to the EPL on the medial side and therefore crossed the mitral cell layer (MCL) in both the lateral and medial halves of the $\mathrm{OB}$. The position of each MCL was identified as the point at which the local field potential evoked by LOT stimulation reversed polarity (Phillips et al., 1963; Schneider and Scott, 1983; Griff et al., 2008; Fig. 1E). To document the accuracy of this method in the present study, Chicago Sky Blue was ejected by iontophoresis at the LOT-evoked reversal point in six micropipette penetrations; in every case, histology indicated that the resulting dye mark was located in the MCL.

Immediately after the end of data collection, the animal was given an overdose of anesthetic and perfused transcardially with PBS containing heparin ( 2 units/ml), followed by $10 \%$ phosphate-buffered formalin. The site of each chronic stimulating and recording electrode was marked using the Prussian blue reaction and $50 \mu \mathrm{m}$ frozen sections were cut, stained with cresyl violet, and examined under a microscope to verify electrode placement.

$M / T$ cells. M/T cells were recorded using either tungsten microelectrodes or glass micropipettes broken to a tip diameter of $2-4 \mu \mathrm{m}$ and filled with $2 \mathrm{M} \mathrm{NaCl}$. Units were classified as M/T cells if they could be driven antidromically by LOT stimulation (Fig. $1 C$ ). Highly phasic cells were excluded from analysis due to the difficulty of distinguishing stimulation-induced inhibition from spontaneous fluctuations in firing rate. $\mathrm{M} / \mathrm{T}$ cells with stable spontaneous firing rates were tested for the ability of AF and LOT stimulation to inhibit spontaneous firing and for the effect of a potentiation treatment on that ability. For this purpose, AF current intensity was set to $85 \%$ of the threshold for LOT activation and LOT current intensity to a value that evoked a population EPSP that was $50 \%$ of its maximum amplitude. Single-pulse AF and LOT stimulation was alternated at $2.5 \mathrm{~s}$ intervals for $4 \mathrm{~min}$ before and $12 \mathrm{~min}$ after a potentiation treatment. Peristimulus time histograms with $5 \mathrm{~ms}$ bins were constructed of $\mathrm{M} / \mathrm{T}$ cell firing rates for every $4 \mathrm{~min}$ of data, representing $48 \mathrm{AF}$ and $48 \mathrm{LOT}$ stimulation trials. The duration of stimulation-evoked inhibition was calculated for each stimulation site and $4 \mathrm{~min}$ period as the length of time that the cell's firing rate was reduced to $<50 \%$ of its prestimulation mean.

Presumed granule cells. We classified cells as presumed granule cells if they were recorded within the internal plexiform layer or GCL (i.e., deeper than the reversal point of the LOT-evoked potential) and driven synaptically by either AF or LOT stimulation. In addition to granule cells, these layers also contain several types of short-axon cells, including Blanes, Golgi, and Cajal cells (Price and Powell, 1970; Schneider and Macrides, 1978; López-Mascaraque et al., 1986), at least some of which can be excited by M/T cells (Eyre et al., 2008) and/or AF axons (Boyd et al., 2012), raising the possibility that we recorded from some short-axon cells as well as granule cells. However, short-axon cells have an estimated population of $\sim 13,500$ in the internal plexiform layer and GCL of the rat (Eyre et al., 2009), contrasting sharply with granule cells, which have an estimated population of 3,100,000 in the rat (Struble and Walters, 1982). This yields a ratio of granule cells to short-axon cells of $\sim 230: 1$, implying that the overwhelming majority of cells recorded from these layers using a blind recording technique should be granule cells rather than shortaxon cells. This conclusion is supported by evidence from Cazakoff et al. (2014), who labeled GCL cells using blind juxtacellular recording in vivo and found that $>97 \%$ of labeled cells were granule cells. Based on this evidence, the probability of recording from granule cells rather than short-axon cells in the present experiment should be quite high, allowing our sample of cells from the internal plexiform layer and GCL to provide an accurate characterization of the response of granule cells to AF and LOT stimulation.

We recorded presumed granule cells using glass micropipettes broken to a tip diameter of $2-4 \mu \mathrm{m}$ and filled with $2 \mathrm{M} \mathrm{NaCl}$. Synaptically driven cells were identified by advancing the microelectrode from one MCL to the other in small steps ( 2 or $4 \mu \mathrm{m}$ ) while alternately stimulating the AF and LOT at substantial current intensities: the AF current was set to $85 \%$ of the threshold for LOT activation and the LOT current to a value that evoked a population EPSP that was $85 \%$ of maximum amplitude. Once a cell was found that was driven by stimulation of one site, the current intensity for that site was gradually reduced to determine the threshold current for driving that cell. The median latency at which the cell was driven was then determined using a current intensity $15 \%$ above that threshold; for cells that fired more than once after each stimulation, the latency recorded was that of the first action potential evoked on each trial. The majority of cells were driven exclusively by one of the two stimulation sites. Cells that responded at least occasionally to stimulation of either site were classified as preferentially driven by 1 site if the ratio of APs evoked by the 2 sites was 5:1 or greater.

Each recorded cell was characterized by its depth below the MCL, calculated as its proportional distance between the MCL (the point at which the LOT-evoked potential reversed polarity) and the core of the $\mathrm{OB}$ (the midpoint between the MCLs in the lateral and medial halves of 
the $\mathrm{OB})$. Once identified and classified, each cell was tested for the effect of a potentiation treatment on AF- or LOT-evoked firing using a peristimulus time histogram protocol similar to that used with M/T cells, with the current intensity for test stimulation at the preferred stimulation site set to $15 \%$ above the threshold for driving that cell.

\section{Antidromic activation of $P C$ neurons projecting to the $O B$}

PC neurons activated antidromically from the GCL of the OB were identified as follows. A stainless steel microelectrode with a large $(150 \mu \mathrm{m})$ tip exposure was advanced into the core of the $\mathrm{OB}$ (identified as the point at which the LOT-evoked potential reached its maximum amplitude) and was used as a stimulation electrode for antidromic activation of centrifugal fibers. A small window was opened in the lateral surface of the skull 3-4 $\mathrm{mm}$ dorsal to the $\mathrm{PC}$ and $1-4 \mathrm{~mm}$ posterior to the chronically implanted LOT/AF-stimulating electrode. A stainless steel microelectrode with an $8 \mu \mathrm{m}$ tip exposure was advanced through this window into the PC in small steps ( 4 or $6 \mu \mathrm{m}$ ) while stimulating the $\mathrm{OB}$ at a fixed intensity $(600-1000 \mu \mathrm{A}$ in different animals) to identify PC neurons driven by $\mathrm{OB}$ stimulation. All electrode penetrations passed first through the agranular insular cortex and then entered the PC, passing through layer III and layer II in succession (Fig. 1B). Neurons were classified as being antidromically driven from the OB if: (1) they had a sharp threshold for activation; (2) they exhibited negligible variation in latency at near-threshold stimulation intensities; and (3) if spontaneously active, they exhibited collision between spontaneous orthodromic action potentials and evoked antidromic action potentials or, if not spontaneously active, they followed paired-pulse stimulation at interpulse intervals of 3 $\mathrm{ms}$ or less. Iron ions were deposited using brief anodal current $(1 \mu \mathrm{A}$ for $5 \mathrm{~s}$ ) at several identified points along each electrode tract during withdrawal and were subsequently stained using the Prussian blue reaction, allowing the position of each antidromically activated cell to be reconstructed from histological sections.

\section{Data analysis}

Recordings were digitized using a 12-bit analog-to-digital converter at 3.33 or $10 \mathrm{kHz}$ (local field potentials) or $20 \mathrm{kHz}$ (unit activity). Single units were isolated using template recognition and their response to AF or LOT stimulation was assessed using peristimulus time histograms (EGAA; R.C. Electronics). Statistical analysis was conducted in SPSS software by two-tailed $t$ test or ANOVA. Significant ANOVAs were followed by pairwise comparisons where appropriate, using the Bonferroni correction to adjust $p$ values to compensate for multiple comparisons. Homogeneity of variance assumptions for repeated-measures ANOVAs were assessed using Mauchly's test and degrees of freedom and probability levels were adjusted as needed using the Greenhouse-Geisser procedure for $\varepsilon<0.5$ and the Huynh-Feldt procedure for $0.5<\varepsilon<1$ (Huynh and Feldt, 1976); in such cases, ANOVA results are reported with the original degrees of freedom but with the adjusted $p$ values. Effect size is reported for all significant analyses, using Cohen's $d$ for $t$ tests and partial $\eta$-squared $\left(\eta_{p}^{2}\right)$ for ANOVAs.

\section{Results}

\section{Induction and expression of potentiation under} urethane anesthesia

Because we have previously documented potentiation of AFevoked local field potentials in the $\mathrm{OB}$ only in waking animals (Stripling and Patneau, 1999; Stripling and Galupo, 2008), an initial analysis was done to characterize the induction and expression of this potentiation under urethane anesthesia. Data were examined for 5 naive and 9 potentiated animals that received 3 potentiation treatments under urethane at intervals of $1-2 \mathrm{~h}$. Potentiation was monitored using the area of the potentiated component (Fig. 1D) from $4 \mathrm{~min}$ before to $12 \mathrm{~min}$ after each potentiation treatment; for analysis, the area of the potentiated component was averaged over consecutive 4 min periods. A twofactor within-subjects ANOVA (four time periods $\times$ three potentiation treatments) was used to assess the pattern of change in the potentiated component over time within each group of animals.
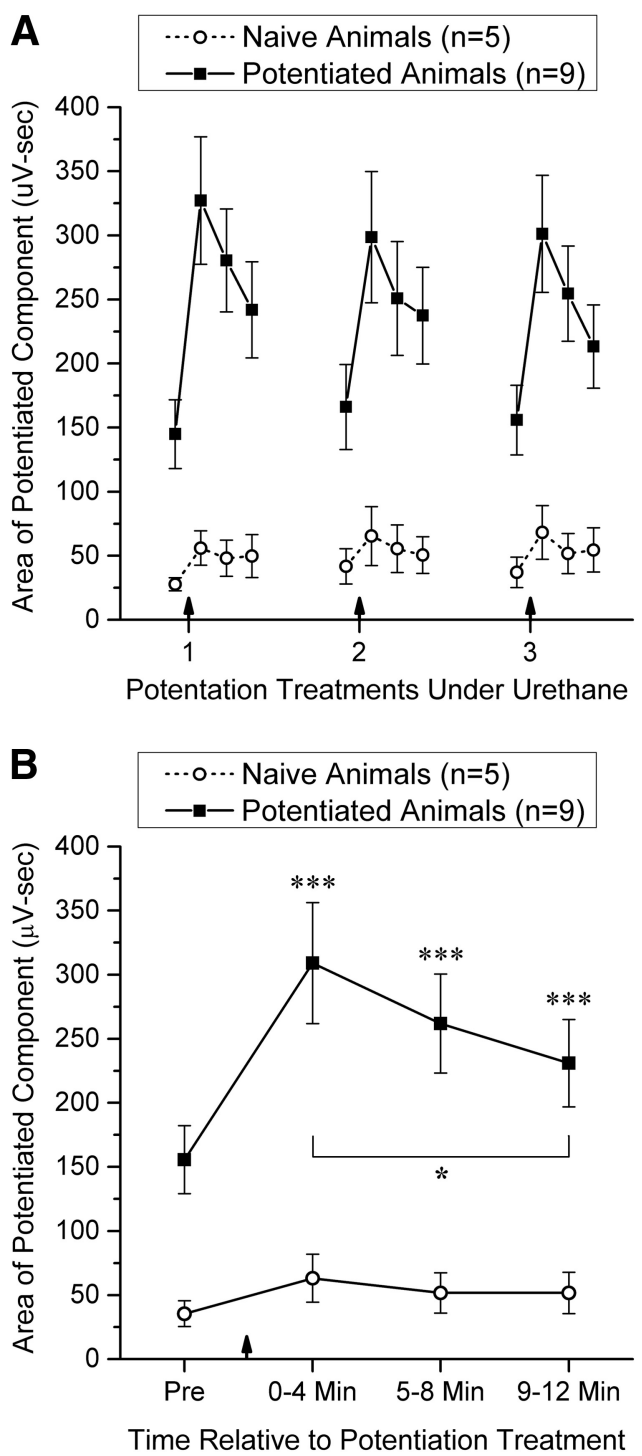

Figure 2. The induction and expression of potentiation of the local field potential evoked in the $\mathrm{GCL}$ by AF stimulation under urethane anesthesia. $\boldsymbol{A}$, Changes in the area of the potentiated component in both naive and potentiated animals across 3 potentiation treatments spaced 1-2 h apart. Data points (mean \pm SEM) represent the average of 48 potentials evoked over a 4 min period before and $0-4,5-8$, and $9-12$ min after each potentiation treatment (indicated by a vertical arrow). $\boldsymbol{B}$, Time course of potentiation pooled across the three potentiation treatments. Significant pairwise comparisons using the Bonferroni correction for multiple comparisons: Increase from Pre, ${ }^{* * *} p<0.001$; decline from peak value $(0-4 \mathrm{~min}),{ }^{*} p<0.05$.

Figure $2 A$ illustrates the results. Naive animals exhibited a small but significant change in the potentiated component across the 4 time periods $\left(F_{(3,12) \text { time }}=6.24, p=0.015, \eta_{p}^{2}=0.61\right)$ and potentiated animals a much larger significant change $\left(F_{(3,24)}\right.$ time $=$ $35.46, p<0.0001, \eta_{p}^{2}=0.82$ ). As Figure $2 A$ indicates, this change was due to potentiation induced by high-frequency AF stimulation. The overall expression of potentiation did not change significantly across the 3 potentiation treatments for either naive animals $\left(F_{(2,8) \text { treatment }}=1.21, \quad p=0.35\right)$ or potentiated animals $\left(F_{(2,16) \text { treatment }}=0.50, p=0.62\right)$, nor did the temporal pattern and magnitude of potentiation change significantly across the 3 treatments for either naive animals $\left(F_{(6,24)}\right.$ time $\times$ treatment $=0.80, p=$ $0.47)$ or potentiated animals $\left(F_{(6,48)}\right.$ time $\times$ treatment $=1.85, p=$ 0.12 ). Between-group comparisons indicated that potentiated animals exhibited a significantly greater evoked-potential area 
than naive animals before any potentiation treatment had been administered under urethane $\left(t_{(12)}=3.20, p=0.008\right.$, Cohen's $d=1.78$; Fig. $2 A$, first time point) and a significantly greater increase in that area from before the first potentiation treatment to $0-4$ min afterward $\left(t_{(12)}=3.97, p=0.002\right.$, Cohen's $d=2.21$ ).

Because the main effect for time was significant for both naive and potentiated animals in the two-factor ANOVAs, the change in the expression of potentiation after potentiating stimulation was examined in more detail. Figure $2 B$ shows the time course of potentiation pooled across the three potentiation treatments for each group, as well as all significant pairwise comparisons of the four data points for each group using two-tailed $t$ tests, with $p$ values adjusted using the Bonferroni correction. In potentiated animals, the expression of potentiation was significantly elevated for all 3 time points after potentiating stimulation, although it declined significantly from $0-4$ min to $9-12$ min after potentiating stimulation (Fig. 2B). A separate set of pairwise comparisons in potentiated animals indicated that there were no significant differences between the baseline (Pre) values for the 3 potentiation treatments (all $t$ values $<1$ ), indicating that the expression of potentiation returned fully to its baseline value between treatments. No pairwise comparisons were significant for control animals.

These results demonstrate that reliable potentiation can be induced and expressed under urethane anesthesia, and that this potentiation is significantly more robust in animals that have received previous potentiation treatments while awake. Furthermore, the expression of potentiation does not change significantly over several potentiation treatments at $1-2 \mathrm{~h}$ intervals, permitting the effect of high-frequency AF stimulation on singlecell activity to be examined in several cells recorded in succession from a single animal.

\section{High-frequency AF stimulation potentiates the duration of} $\mathrm{M} / \mathrm{T}$ cell inhibition by AF test stimulation

The ability of AF and LOT stimulation to inhibit spontaneous firing of M/T cells and the effect of a potentiation treatment on this ability was examined in a total of $39 \mathrm{M} / \mathrm{T}$ cells recorded from 25 animals under urethane anesthesia. Of these, 14 cells were recorded from naive animals and 25 from potentiated animals. All 39 cells were driven antidromically by LOT stimulation (Fig. $1 C$ ), with an antidromic threshold of $89 \pm 85 \mu \mathrm{A}$ and an antidromic latency of $2.1 \pm 0.7 \mathrm{~ms}$ (mean $\pm \mathrm{SD}$ ).

A detailed illustration of the effect of AF and LOT stimulation on the firing pattern of an $\mathrm{M} / \mathrm{T}$ cell recorded in a potentiated animal is shown in Figure 3, $A$ and $B$. Examination of the figure reveals that $\mathrm{AF}$ test stimulation initially produced a brief inhibition of $\mathrm{M} / \mathrm{T}$ cell firing, and that the duration of this effect was substantially increased after a potentiation treatment, as was the amplitude and duration of the local field potential evoked in the GCL by AF stimulation. LOT stimulation also produced a brief inhibition of $\mathrm{M} / \mathrm{T}$ firing, but the duration of this effect was unaffected after high-frequency AF stimulation, as was the LOTevoked potential, indicating that this potentiation was selective to AF-evoked responses rather than caused by an overall alteration in the cell's excitability. Statistical analysis indicated that highfrequency AF stimulation significantly potentiated the duration of $\mathrm{M} / \mathrm{T}$ inhibition by $\mathrm{AF}$ stimulation only in potentiated animals (Fig. 3C). A 1-factor repeated-measure ANOVA on AF-induced inhibition of $\mathrm{M} / \mathrm{T}$ firing across 4 -min time periods from $4 \mathrm{~min}$ before the potentiation treatment to $12 \mathrm{~min}$ afterward revealed a significant increase in the duration of inhibition after highfrequency AF stimulation in potentiated animals $\left(F_{(3,72)}=23.21\right.$,
A AF Stimulation $(160 \mu \mathrm{A}) \quad$ LOT Stimulation $(27 \mu \mathrm{A})$
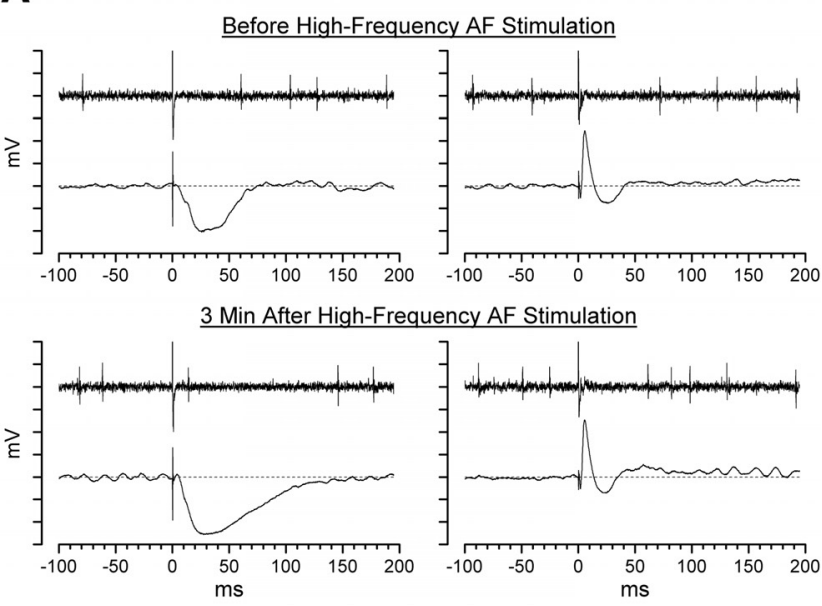

B AF Stimulation $(160 \mu \mathrm{A}) \quad$ LOT Stimulation $(27 \mu \mathrm{A})$

Before High-Frequency AF Stimulation
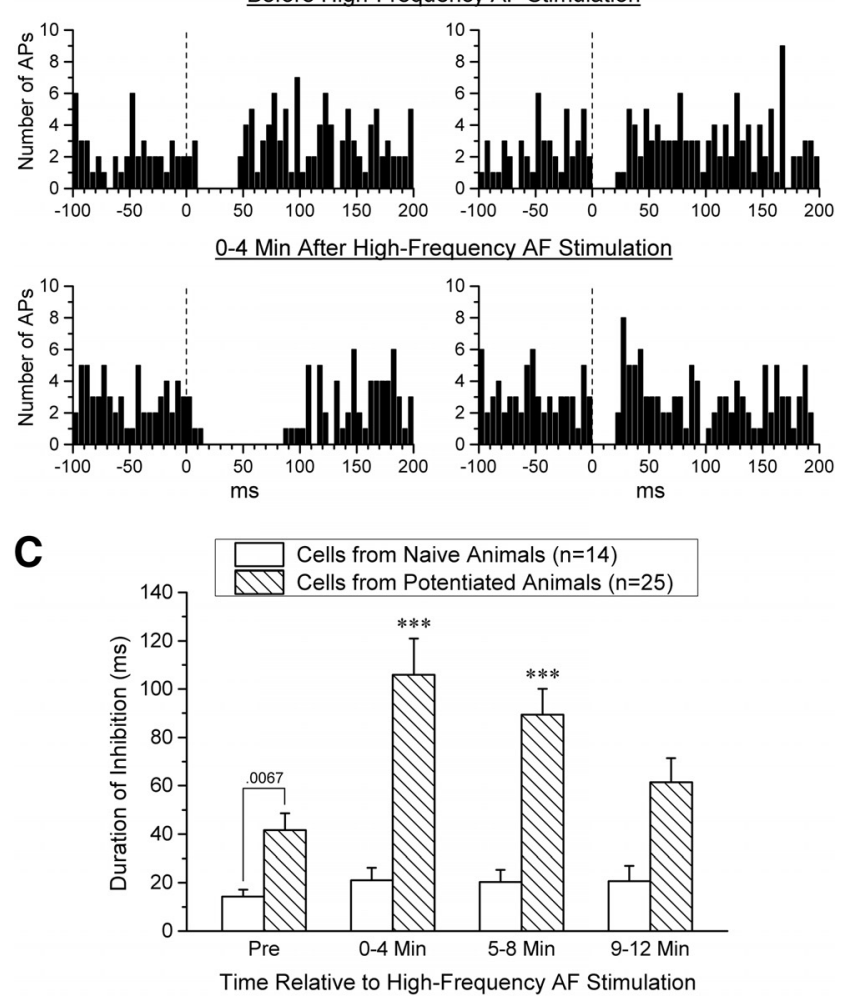

Figure 3. Effect of a potentiation treatment on the response of M/T cells to AF and LOT stimulation in naive and potentiated animals. $A$, Single trials recorded before and $3 \mathrm{~min}$ after high-frequency AF stimulation in a potentiated animal. For each plot, the top trace shows action potentials recorded from an $\mathrm{M} / \mathrm{T}$ cell and the bottom trace the concurrently recorded local field potential in the GCL. Both the duration of M/T cell inhibition and the local field potential evoked by AF stimulation were potentiated and the duration of inhibition corresponds well with the duration of the local field potential. In contrast, the responses evoked by LOT stimulation were unchanged. Each tick mark on the ordinate represents $1 \mathrm{mV}$. B, Peristimulus time histograms for the same $M / T$ cell illustrated in $A$. Each histogram is based on 48 trials recorded over 4 min; each bin represents $5 \mathrm{~ms}$. Stimulation was alternated between the AF and LOT electrodes at $2.5 \mathrm{~s}$ intervals to provide information regarding both stimulation sites over the same time period. $C$, Duration of inhibition produced by AF test stimulation before and after a potentiation treatment (mean + SEM). M/T cells were inhibited significantly longer after high-frequency AF stimulation in cells recorded from potentiated animals $(n=25)$, but not in cells recorded from naive animals $(n=14)$. Significant differences from Pre using the Bonferroni correction for multiple comparisons, ${ }^{* * *} p<0.001$. Furthermore, cells recorded from potentiated animals were inhibited significantly longer than cells from naive animals before high-frequency AF stimulation was administered (two-tailed $t$ test). 
Table 1. Characteristics of neurons in the internal plexiform layer and GCL of the OB that were selectively activated by stimulation of either the AF (type A cells) or the LOT (type L cells)

\begin{tabular}{|c|c|c|c|c|c|}
\hline & Type A cells & Type L cells & $t^{a}$ & $p$ & Cohen's d \\
\hline$n$ & 21 & 29 & & & \\
\hline Threshold & $219 \pm 96 \mu \mathrm{A}(50-350)$ & $139 \pm 95 \mu \mathrm{A}(40-450)$ & 2.90 & 0.0056 & 0.83 \\
\hline Latency & $21.5 \pm 6.8 \mathrm{~ms}(10-36)$ & $6.0 \pm 2.8 \mathrm{~ms}(4-18)$ & 11.03 & $<0.0001$ & 3.16 \\
\hline Proportional depth ${ }^{b}$ & $0.62 \pm 0.14(0.28-0.94)$ & $0.32 \pm 0.23(0.00-0.86)$ & 5.17 & $<0.0001$ & 1.48 \\
\hline
\end{tabular}

Data are shown as mean \pm SD (range).

${ }^{a}$ Comparison between type A and type L cells (two-tailed $t$ test, $d f=48$ ).

${ }^{b}$ Proportional distance of each cell from the MCL to the core of the $O B$.

$\left.p<0.0001, \eta_{p}^{2}=0.49\right)$, but no significant effect in naive animals $\left(F_{(3,39)}=0.51, p=0.68\right)$. In addition, the duration of inhibition produced by AF stimulation before the potentiation treatment was significantly greater in potentiated animals than in naive animals $\left(t_{(37)}=2.87, p=0.0067\right.$, Cohen's $\left.d=0.96\right)$. In contrast, there was no significant change over time in the duration of inhibition produced by LOT stimulation in either potentiated animals $\left(F_{(3,72)}=0.19, p=0.90\right)$ or naive animals $\left(F_{(3,39)}=1.41\right.$, $p=0.25$; data not shown), nor was there a significant change in the spontaneous firing rate of $\mathrm{M} / \mathrm{T}$ cells in either potentiated animals $\left(F_{(3,72)}=0.79, p=0.50\right)$ or naive animals $\left(F_{(3,39)}=0.97\right.$, $p=0.42$; data not shown $)$, indicating that there was no overall change in $\mathrm{M} / \mathrm{T}$ cell excitability.

Presumed granule cells activated by AF stimulation occur deeper in the GCL than those activated by LOT stimulation Cells were identified as presumed granule cells if they were located below the MCL and were driven synaptically by AF and/or LOT stimulation. A total of 58 such cells were recorded extracellularly from 30 microelectrode penetrations in 23 animals. Twenty-nine of the 58 cells were recorded in the lateral half of the $\mathrm{OB}$ and 29 in the medial half. The mean distance from the MCL to the core of the OB was $429 \pm 68 \mu \mathrm{m}$ and the mean depth of the cells below the MCL was $193 \pm 108 \mu \mathrm{m}$, ranging from near the reversal point of the LOT-evoked potential to $380 \mu \mathrm{m}$ below it. Of the 58 cells, six were excluded from analysis due to a high spontaneous firing rate that made it difficult to separate evoked from spontaneous activity. Of the 52 remaining cells, 45 never fired spontaneously and the remaining 7 fired only rarely $(<1$ $\mathrm{AP} / \mathrm{s})$. Twenty-one of these cells were classified as preferentially driven by AF stimulation (type A cells) and 29 as preferentially driven by LOT stimulation (type L cells). The remaining two cells were readily driven from either site and, because of their small number, are not discussed further here. Both type A and type L cells were highly selective in their response: 35 of 50 (70\%) responded exclusively to the preferred stimulation site and all had a preference ratio of at least 5:1.

The characteristics of type A and type L cells are summarized in Table 1 and illustrated in Figure 4, $A$ and $B$. The latency at which the two types of cells were driven was significantly longer $\left(t_{(48)}=11.03, p<0.0001\right.$, Cohen's $\left.d=3.16\right)$ and more variable for type A than for type L cells and corresponded well with the latency of the population EPSP evoked in the GCL by each fiber system (Fig. 4A, B; Table 1). Furthermore, type A cells occupied a significantly deeper position in the $\mathrm{OB}$ than did type $\mathrm{L}$ cells $\left(t_{(48)}=5.17, p<0.0001\right.$, Cohen's $\left.d=1.48\right)$, although with substantial overlap between the two populations (Fig. 4C, Table 1). This finding is consistent with previous observations that projections to the $\mathrm{OB}$ from the $\mathrm{PC}$ terminate primarily in the deep portion of the GCL (Luskin and Price, 1983; Laaris et al., 2007), where they produce an EPSC in granule cells (Balu et al., 2007; Boyd et al., 2012).

\section{Presumed granule cells activated by AF stimulation are} detected more frequently in potentiated than in naive animals Of the 50 type A and type L cells, 15 were recorded from naive animals and 35 from potentiated animals. In naive animals, type A cells occurred significantly less often (2/15, or $13 \%)$ than type L cells $(13 / 15$, or $87 \%), \chi^{2}(1)=6.67, p<0.01$, whereas the two cell types were detected with similar frequency in potentiated animals (19/35, or $55 \%$, were type A and $16 / 35$, or $45 \%$, were type L), $\chi^{2}(1)=0.11, p>0.70$. This discrepancy between naive and potentiated animals in the relative frequency of the two cell types suggests that potentiation of the AF input to the OB facilitated detection of type A cells. However, the step size in our first 10 electrode penetrations was not held rigorously constant throughout the entire extent of the GCL, potentially biasing the search procedure toward the detection of one cell type. To provide a rigorous examination of the occurrence of the two cell types, a search procedure that was unbiased with respect to depth was used in the remaining 20 electrode penetrations (seven in naive animals and 13 in potentiated animals). This was accomplished by advancing the microelectrode in steps of fixed size ( 2 or $4 \mu \mathrm{m}$ in different penetrations) from one MCL to the other and stimulating through both electrodes in turn at each step. Using this procedure, which yielded a total of 40 type A and type L cells, the incidence of type A cells was significantly higher in potentiated than in naive animals $\left(t_{(18)}=2.60, p=0.018\right.$, Cohen's $d=1.21$; Fig. $5 A$ ). In contrast, no significant difference was found in the incidence of type L cells in naive versus potentiated animals $\left(t_{(18)}=\right.$ $0.56, p=0.58)$.

\section{High-frequency AF stimulation potentiates AF activation of presumed granule cells}

If the increased duration of AF-evoked inhibition of M/T cells seen after a potentiation treatment is due to increased synaptic drive of granule cells by AF projections to the OB, then type A cells should exhibit a corresponding increase in AF-evoked APs. Because of the rarity of type A cells in naive animals (Fig. $5 A$ ), this possibility was examined only in cells recorded in potentiated animals. Furthermore, because of difficulty in holding these cells for an extended period of time, data are reported only for the last 4 min preceding and first $4 \mathrm{~min}$ after a potentiation treatment. The results are illustrated in Figure $4 A$ and summarized in Figure $5 B$. As predicted, there was a significant increase in firing of type A cells evoked by AF stimulation after a potentiation treatment $\left(t_{(12)}=4.40, p=0.0009\right.$, Cohen's $\left.d=1.16\right)$. Type L cells exhibited a small, nonsignificant, increase in firing evoked by LOT stimulation $\left(t_{(6)}=1.75, p=0.13\right)$. A comparison between the two cell types indicated that, although type A cells exhibited a 


\section{A Type A cells $\quad \underline{\text { Type } L \text { cells }}$}
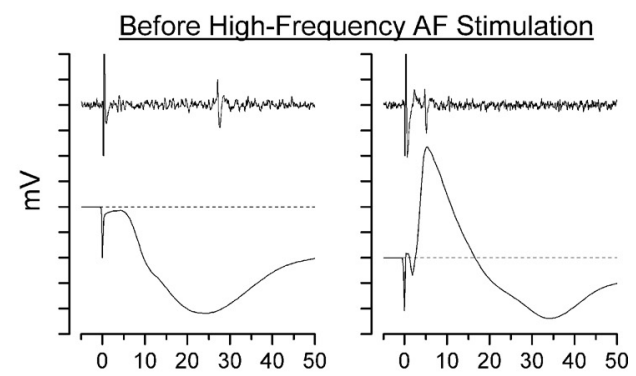

3 Min After High-Frequency AF Stimulation
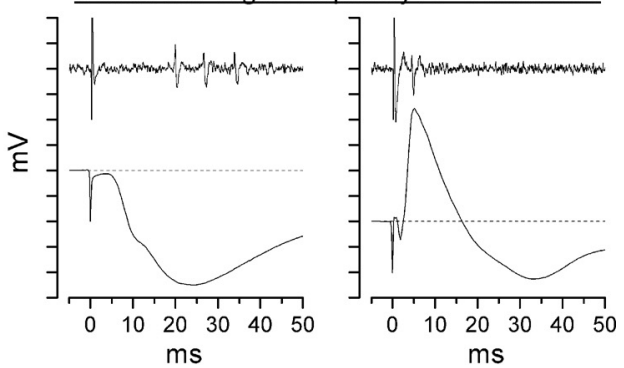

B Latency for Synaptic Activation
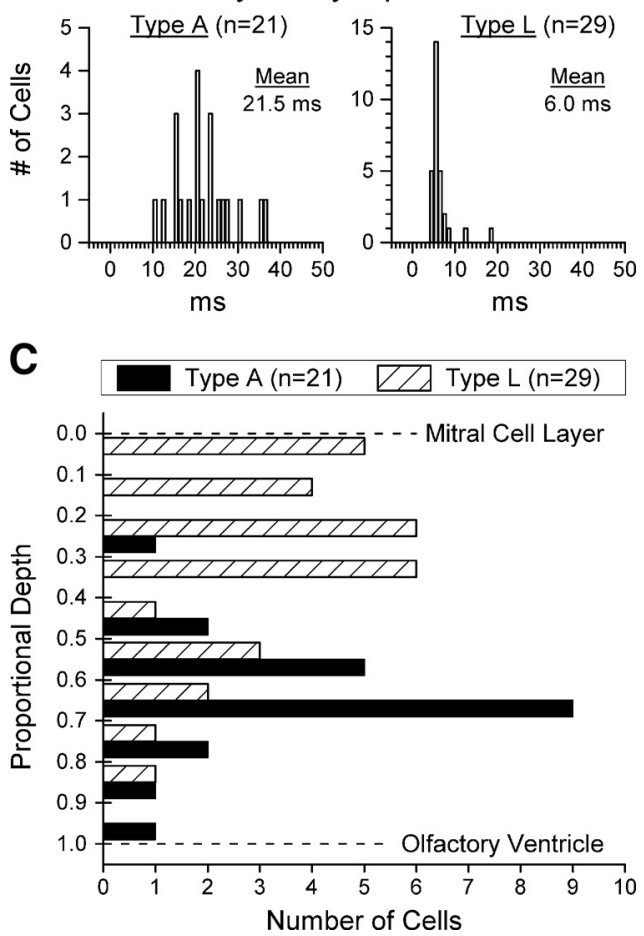

Figure 4. Characteristics of the two types of presumed granule cells identified in this study: type A cells, driven selectively by AF stimulation, and type $L$ cells, driven selectively by LOT stimulation. $A$, Illustration of the response of each type of cell to its preferred stimulation and of the local field potential evoked in the GCL by the same stimulation. In each case, the cell is activated near the peak of the population EPSP evoked in the $\mathrm{GCL}$ by the stimulation that drives it. Neither of the cells illustrated here ever fired spontaneously or in response to the other stimulation site. Top traces were recorded before, and bottom traces 3 min after, a potentiation treatment. Each tick mark on the ordinate represents $1 \mathrm{mV}$. Stimulation artifacts have been clipped at a fixed amplitude. $\boldsymbol{B}$, Distribution of firing latencies for the 21 type $A$ and 29 type $L$ cells recorded in this study (1 ms bins) before high-frequency AF stimulation. The time scales in $\boldsymbol{A}$ and $\boldsymbol{B}$ are in register to facilitate comparison of the evoked potentials shown in $\boldsymbol{A}$ and the distribution of cell latencies shown in B. C, Depth distribution of the 21 type $A$ and 29 type $L$ cells recorded in this study. Type $L$ cells occurred primarily in the superficial half of the $\mathrm{GCL}$ and type A cells primarily in the deep half of the $\mathrm{GCL}$.

\section{A Number of Cells Per Standardized Search}
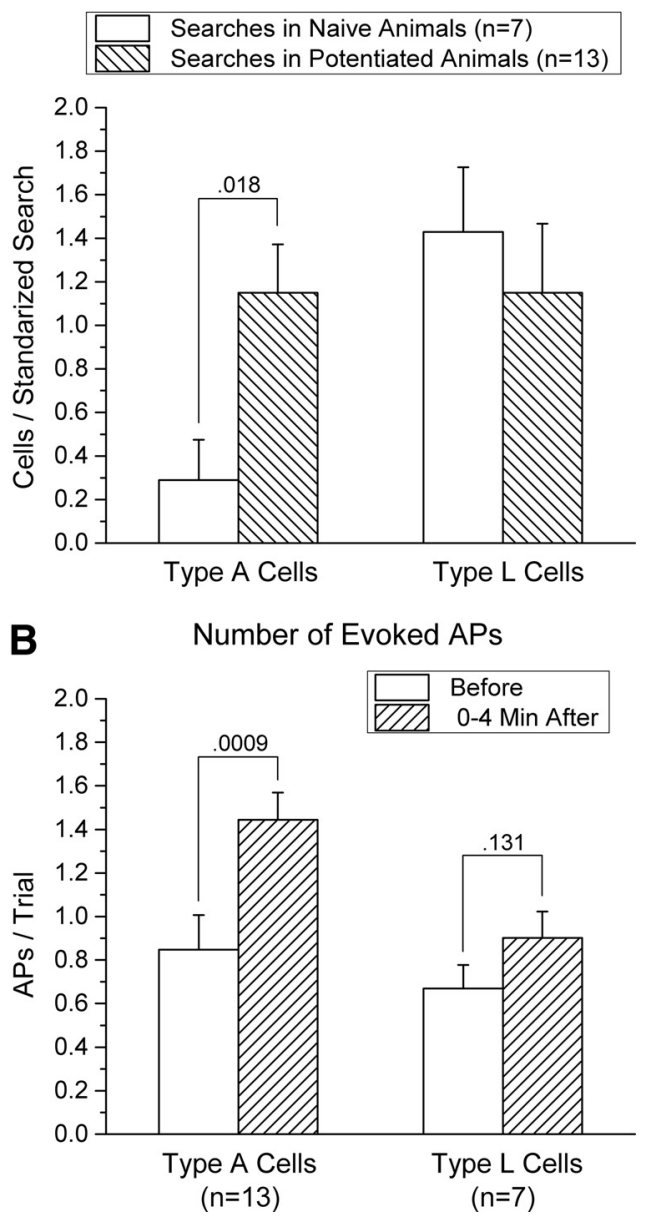

Figure 5. $A$, Comparison of the incidence of type A and type $L$ cells in naive and potentiated animals (mean + SEM). A standardized search procedure was used to provide an unbiased estimate of the relative incidence of the two types of cells: the recording electrode was advanced in the horizontal plane from the lateral MCL to the medial MCL in fixed steps (either 2 or $4 \mu \mathrm{m}$ for different searches), with stimulation of both the AF and LOT occurring at each step. Type $L$ cells were found at similar rates in searches conducted in potentiated and naive animals, but type A cells occurred significantly more often in potentiated than in naive animals. Data are based on 20 standardized searches: seven conducted in naive animals and 13 conducted in potentiated animals. $\boldsymbol{B}$, Effect of a potentiation treatment on the mean number of action potentials evoked per stimulation trial in type A and type L cells. Data (mean + SEM) are shown for cells recorded from potentiated animals only; data from naive animals were not included because of the rarity of type A cells in those animals $(\boldsymbol{A})$. Type A cells exhibited a significant increase in firing evoked by AF stimulation, whereas type $L$ cells exhibited a smaller, nonsignificant increase to LOT stimulation.

considerably larger increase in evoked firing than type L cells after a potentiation treatment, this difference approached but did not reach significance $\left(t_{(18)}=1.74, p=0.10\right)$. APs were evoked only rarely by the nonpreferred stimulation site in both cell types $(<2 \%$ of trials), and this rate did not change significantly after high-frequency AF stimulation $(t<1$ for each cell type; data not shown).

\section{Conduction velocity of $\mathrm{AF}$ axons projecting to the $\mathrm{OB}$}

As Figure 4 and Table 1 indicate, the latency for type A cells to fire after AF stimulation was substantially longer and more variable across cells than that for type L cells after LOT stimulation, raising the question of whether type A cells were activated monosynaptically or polysynaptically after AF stimulation. We examined whether the conduction time of PC AFs 
Table 2. Characteristics of neurons in the PC activated antidromically from the GCL of the $\mathrm{OB}(n=43)$

\begin{tabular}{lcc}
\hline & Mean \pm SD & Range \\
\hline Antidromic threshold & $388 \pm 264 \mu \mathrm{A}$ & $100-1000 \mu \mathrm{A}$ \\
Frequency following (minimum & $2.3 \pm 0.5 \mathrm{~ms}$ & $1.5-4.0 \mathrm{~ms}$ \\
$\quad$ & & \\
interval) $^{a}$ & $19.7 \pm 7.2 \mathrm{~ms}$ & $7-38 \mathrm{~ms}$ \\
Antidromic latency $_{\text {Conduction velocity (lower limit) }}{ }^{b}$ & $0.60 \pm 0.29 \mathrm{~m} / \mathrm{s}$ & $0.26-1.50 \mathrm{~m} / \mathrm{s}$ \\
Anterior-posterior distance from $^{\text {bregma }}$ & $\mathrm{B}-0.7 \pm 1.1 \mathrm{~mm}$ & $\mathrm{~B}+1.4 \mathrm{to} \mathrm{B}-1.9 \mathrm{~mm}$ \\
\hline
\end{tabular}

${ }^{a}$ All but one cell followed paired-pulse stimulation at intervals of $3.0 \mathrm{~ms}$ or less. The one cell with a larger minimum interval $(4.0 \mathrm{~ms}$ ) was spontaneously active and exhibited collision between spontaneous and evoked action potentials.

${ }^{b} \mathrm{~A}$ lower-limit estimate of conduction velocity was calculated using the cell's antidromic latency and the straightline distance between stimulation and recording sites.

'Estimated from Paxinos and Watson (1997).

is compatible with the long latency at which type A cells fired by measuring antidromic activation times from the $\mathrm{OB}$ to the PC. We stimulated the core of the GCL in the posterior portion of the $\mathrm{OB}(1.3 \pm 0.4 \mathrm{~mm}$ anterior to the boundary between the $\mathrm{OB}$ and the anterior olfactory nucleus; range: $0.8-$ $1.8 \mathrm{~mm}$ ) while searching in the PC (1-4 mm posterior to the AF stimulation site) for neurons that were driven antidromically from the GCL.

A total of 43 neurons from 14 electrode penetrations in nine animals were identified that could be isolated reliably as single units and were antidromically activated from the $\mathrm{OB}$ (Table 2). Five cells fired spontaneously, and each of these exhibited collision between spontaneous orthodromic and evoked antidromic action potentials; all cells that did not fire spontaneously and thus could not be tested for collision followed paired-pulse stimulation at intervals of $3 \mathrm{~ms}$ or less (Fig. 6A). The measured antidromic latencies of these cells (Fig. 6B) were long, varied widely across cells, and closely paralleled the latencies at which AF stimulation activated type A cells (Fig. 6C), from which they did not differ significantly $\left(t_{(62)}=0.96, p=0.34\right)$. Histological analysis indicated that the 43 cells we identified as being activated antidromically from the GCL of the $\mathrm{OB}$ occurred over the entire anterior-posterior extent of our recording range within the $\mathrm{PC}$, including portions of both the anterior and posterior PC (Table 2 ), and were widely distributed throughout layers II and III of the PC, including the ventral bank of the rhinal fissure near the boundary between the PC and agranular insular cortex.

It should be noted that, of necessity, our sample was biased toward neurons with longer antidromic latencies. Stimulation of the GCL sometimes evoked a cluster of multiple-unit activity in the PC at the latency of the LOT-evoked population EPSP (especially in layer II). Due to their short latency, it is probable that these cells were activated orthodromically via axons in the LOT; however, we could not reliably isolate single cells from such clusters and thus were unable to rule out the possibility that some of these cells might be activated antidromically from the GCL.

\section{Discussion}

The research reported here documents the influence on $\mathrm{OB}$ function of the centrifugal (AF) input to the $\mathrm{OB}$ from the $\mathrm{PC}$ and demonstrates that this input undergoes long-lasting potentiation after repeated high-frequency activation. Animals in which this input had been potentiated in the days preceding testing exhibited a higher incidence of presumed granule cells that could be driven by AF stimulation (type A cells) and an increase in the duration of AF-evoked inhibition of M/T cells. An additional bout of potentiating stimulation delivered to previously potenti- ated animals during single-cell recording produced an increase in the number of action potentials evoked in type A cells by AF stimulation and a concomitant increase in the duration of AFevoked inhibition of M/T cells. These effects were specific to responses evoked by AF stimulation and could not be attributed to overall changes in the excitability of either presumed granule cells or M/T cells. Furthermore, although potentiating treatments delivered to naive animals produced a small amount of potentiation, as measured by the AF-evoked local field potential (Fig. 2), the effect was too weak to result in a significant change in AFevoked inhibition of M/T cells, emphasizing the long-term nature of the effects under study.

Interpretation of these findings hinges upon the assumption that the type A and type L cells described here are granule cells rather than short-axon cells (see Materials and Methods for evidence supporting this assumption). The discussion that follows is predicated upon this assumption and explores its implications for olfactory processing.

\section{Functional characterization of type A and type $L$ cells}

Our distinction between type A and type L cells is based on extracellular recordings that can detect only those synaptic influences powerful enough to evoke action potentials and is not meant to imply that each cell is influenced exclusively by one of these two sources. On the contrary, the reciprocal dendrodendritic microcircuit that interconnects granule and M/T cells can be readily activated locally without triggering action potentials in granule cells (Jahr and Nicoll, 1982; Isaacson and Strowbridge, 1998), so functional activation of granule-cell-to-M/T synapses via LOT stimulation could easily go undetected in our recordings. Evidence indicates that granule cells can operate in at least three different modes to inhibit M/T cells (Chen et al., 2000; Egger et al., 2003, 2005): (1) weak synaptic input from M/T cells via dendrodendritic synapses can trigger $\mathrm{Ca}^{2+}$ influx limited to individual spines, resulting in local recurrent inhibition; (2) stronger input from $\mathrm{M} / \mathrm{T}$ cells can trigger low-threshold $\mathrm{Ca}^{2+}$ spikes that propagate throughout the apical dendrite of granule cells, triggering widespread lateral inhibition; and (3) strong synaptic input at proximal synapses near the soma (e.g., AF input) can trigger $\mathrm{Na}^{+}$action potentials that result in $\mathrm{Ca}^{2+}$ influx throughout the apical dendrite, also producing widespread lateral inhibition. It is less clear whether subthreshold AF synaptic input to granule cells, which occurs at some electrotonic distance from dendrodendritic synapses, can produce functionally significant inhibition of $\mathrm{M} / \mathrm{T}$ cells. Our finding that weak but significant potentiation of the AF-evoked population EPSP in naive animals (Fig. 2) failed to result in a significant increase in AF-evoked M/T cell inhibition suggests that AF potentiation may have little functional impact if it remains subthreshold for action potentials in granule cells.

\section{Possible underlying mechanisms}

The mechanism(s) underlying the potentiation reported here remains to be determined, but several candidate mechanisms can be identified. The most straightforward possibility is LTP at glutamatergic synapses made by AF axons on granule cells, resulting in an increase in the amplitude of EPSPs produced in granule cells by AF stimulation. However, silent synapses lacking AMPA receptors are quite rare in granule cells, in marked contrast to hippocampal CA1 pyramidal cells (Balu et al., 2007), suggesting that LTP due to AMPA-receptor insertion, which plays a prominent role in hippocampal LTP (Isaac et al., 1995), may be difficult to produce at glutamatergic synapses on granule cells. 
A

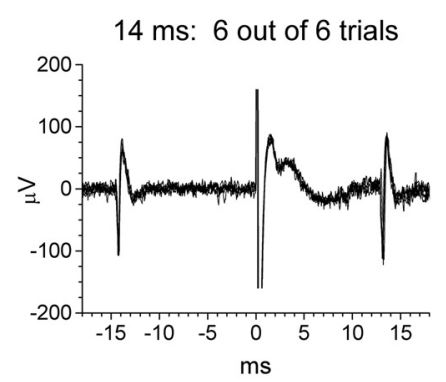

Collision Test

$13 \mathrm{~ms}$ : 0 out of 6 trials

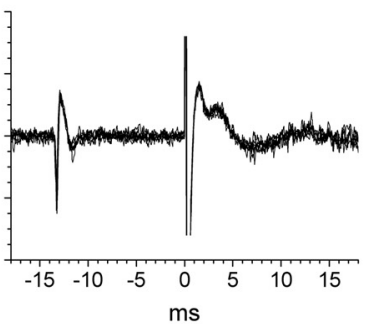

Frequency-Following Test

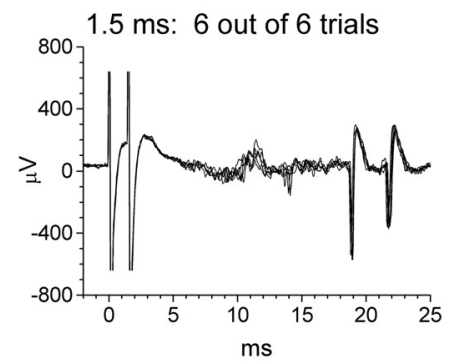

$1.0 \mathrm{~ms}$ : 0 out of 6 trials

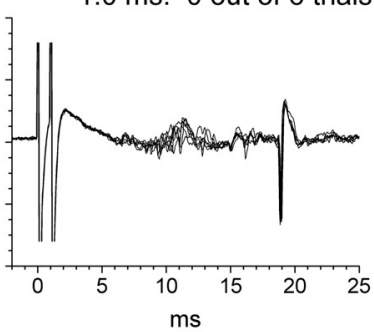

B

Antidromic Latency of

Piriform Cortex Cells $(n=43)$

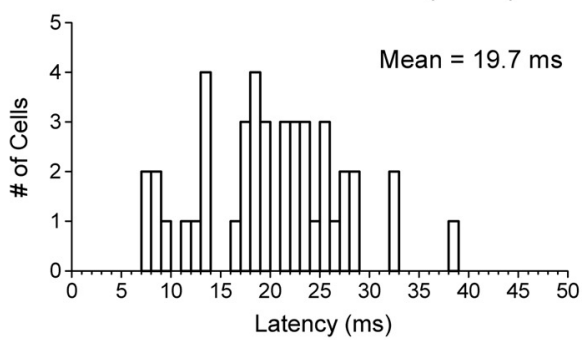

\section{Latency for Synaptic Activation of Type A Cells $(n=21)$}

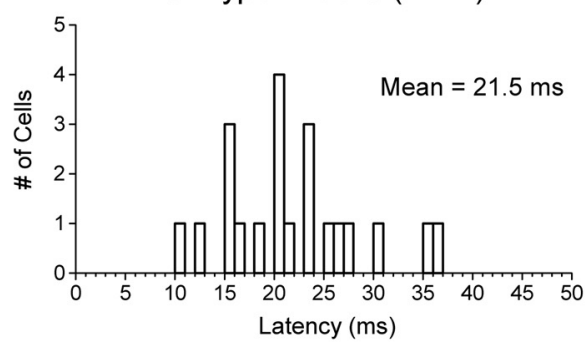

Figure 6. A, Illustration of the tests used to classify cells recorded in the $\mathrm{PC}$ as antidromically driven from the GCL of the OB. Each plot shows the superimposed response in six consecutive trials. Stimulation artifacts have been clipped at a fixed amplitude. Top, Cells that fired spontaneously $(n=5)$ were tested for collision between spontaneous orthodromic and evoked antidromic action potentials. In the example shown here, collision occurred when an antidromic action potential was triggered $13 \mathrm{~ms}$, but not $14 \mathrm{~ms}$, after the spontaneous occurrence of an orthodromic action potential. Bottom, Cells that did not fire spontaneously $(n=38)$ were tested for their ability to follow paired-pulse stimulation at short intervals. The cell illustrated here followed paired-pulse stimulation at a $1.5 \mathrm{~ms}$ interval, but not at a $1.0 \mathrm{~ms}$ interval. $\boldsymbol{B}$, Distribution of latencies at which cells in the $\mathrm{PC}$ were driven antidromically from the $\mathrm{GCL}$ of the $0 \mathrm{~B}(n=43)$. C, Distribution of firing latencies for type $A$ cells $(n=21)$, reproduced from Figure $4 B$. The time scales in $\boldsymbol{B}$ and $\boldsymbol{C}$ are in register to facilitate comparison of the two distributions, which did not differ significantly.

Regardless of whether LTP occurs at AF synapses on granule cells, the observation that potentiation increases the duration as well as the amplitude of the population EPSP evoked in the GRL by AF stimulation (Stripling and Patneau, 1999; Fig. 1D) implies the existence of a separate mechanism capable of generating additional action potentials in PC AFs at long latencies, thereby extending the duration of the population EPSP. AF stimulation activates AF synapses not only on $\mathrm{OB}$ granule cells, but also on neurons in the PC and other AF targets such as the horizontal limb of the diagonal band of Broca (HLDB), opening up a complex tableau of candidate mechanisms. Possibilities with some experimental support include the following: (1) increased network excitability in the PC caused by AF-induced bursting in PC neurons (Hoffman and Haberly, 1989; Tseng and Haberly, 1989; Hoffman and Haberly, 1991); (2) AF activation of HLDB neurons (Ferreyra Moyano and Molina, 1982; Linster and Hasselmo, 2000), in turn causing cholinergic activation of the PC (Linster et al., 1999; Zimmer et al., 1999) of the sort known to produce important changes in PC function (Hasselmo and Bower, 1992; Patil et al., 1998); and (3) AF activation of HLDB neurons projecting to the $\mathrm{OB}$ that, when stimulated repeatedly, cause activation of putative granule cells and inhibition of M/T cells (Nickell and Shipley, 1988).

These observations, while speculative, emphasize that the effects of high-frequency AF stimulation on $\mathrm{OB}$ function are likely to involve multiple sites of action and to prove quite complex. Identification and characterization of these effects will require additional research using a variety of approaches ranging from acute in vitro preparations to longer-term experiments in intact animals.

\section{Functional implications}

The form of plasticity documented here and in previous publications is novel in that its expression is the result of a two-step process. Potentiation must first be induced by high-frequency AF stimulation, which must be repeated several times at distributed intervals for substantial potentiation to occur (Stripling and Patneau, 1999; Stripling and Galupo, 2008). Once established, this potentiation appears to decay substantially within hours (Fig. 2); however, it persists indefinitely in latent form and can be rapidly restored to full strength $8 \mathrm{~d}$ later by a single bout of highfrequency AF stimulation that has little effect in naive animals (Stripling and Galupo, 2008). Persistence of potentiation in latent form is evident even after $32 \mathrm{~d}$, which is the longest interval we have tested (Stripling et al., 1988). Furthermore, although the potentiating treatment used here involved substantial highfrequency stimulation to produce powerful effects that were readily detected by extracellular single-unit recording, we have shown previously that both the induction of potentiation and its retrieval (i.e., the reinstatement of latent potentiation) can be produced by much briefer patterns of stimulation such as repeated paired-pulse stimulation (Stripling et al., 1988). This rapid reinstatement of potentiation by brief $\mathrm{AF}$ activation offers intriguing possibilities as a memory retrieval mechanism. It is important to note that this form of plasticity is readily produced in vivo in adult animals with all neural homeostatic mechanisms intact, offering a degree of physiological relevance not always present in studies using slice preparations in which these homeostatic mechanisms are often damaged or compromised pharmacologically.

The specific findings reported here have several functional implications. Action potentials can be evoked in granule cells by 
odor presentation (Wellis and Scott, 1990; Luo and Katz, 2001; Cang and Isaacson, 2003; Cazakoff et al., 2014) and, as noted above, triggering an action potential in a granule cell converts its influence from local feedback inhibition limited to those dendrodendritic synapses activated directly by $\mathrm{M} / \mathrm{T}$ cells to global activation of all that cell's dendrodendritic synapses, promoting widespread synchronization of activity among M/T cells (Chen et al., 2000; Egger et al., 2003, 2005). Such a change could have important behavioral consequences. For example, Abraham et al. (2010) demonstrated that increasing granule cell inhibition of $\mathrm{M} / \mathrm{T}$ cells using a molecular genetic manipulation improved performance in a difficult olfactory discrimination task. This implies that potentiation of the feedback to the OB from the PC could have a powerful effect on odor processing in the OB, especially if it resulted in increased generation of action potentials in granule cells, as we have shown here for type A cells. Furthermore, because the deep granule cells activated by AF stimulation interact most strongly with mitral cells and internal tufted cells due to the distribution of their apical dendrites in the external plexiform layer (Mori et al., 1983; Orona et al., 1983; Orona et al., 1984; Macrides et al., 1985; Greer, 1987), they influence precisely those output neurons that project most strongly to the PC (Haberly and Price, 1977; Macrides et al., 1985; Nagayama et al., 2010; Igarashi et al., 2012). As a result, the effects reported here could play a significant role in the ability of the PC to regulate its own input by feedback control of M/T excitability.

\section{References}

Abraham NM, Egger V, Shimshek DR, Renden R, Fukunaga I, Sprengel R, Seeburg PH, Klugmann M, Margrie TW, Schaefer AT, Kuner T (2010) Synaptic inhibition in the olfactory bulb accelerates odor discrimination in mice. Neuron 65:399-411. CrossRef Medline

Balu R, Pressler RT, Strowbridge BW (2007) Multiple modes of synaptic excitation of olfactory bulb granule cells. J Neurosci 27:5621-5632. CrossRef Medline

Boyd AM, Sturgill JF, Poo C, Isaacson JS (2012) Cortical feedback control of olfactory bulb circuits. Neuron 76:1161-1174. CrossRef Medline

Cang J, Isaacson JS (2003) In vivo whole-cell recording of odor-evoked synaptic transmission in the rat olfactory bulb. J Neurosci 23:4108-4116. Medline

Carson KA (1984) Quantitative localization of neurons projecting to the mouse main olfactory bulb. Brain Res Bull 12:629-634. CrossRef Medline

Cazakoff BN, Lau BY, Crump KL, Demmer HS, Shea SD (2014) Broadly tuned and respiration-independent inhibition in the olfactory bulb of awake mice. Nat Neurosci 17:569-576. CrossRef Medline

Chen WR, Xiong W, Shepherd GM (2000) Analysis of relations between NMDA receptors and GABA release at olfactory bulb reciprocal synapses. Neuron 25:625-633. CrossRef Medline

Davis BJ, Macrides F (1981) The organization of centrifugal projections from the anterior olfactory nucleus, ventral hippocampal rudiment, and piriform cortex to the main olfactory bulb in the hamster: An autoradiographic study. J Comp Neurol 203:475-493. CrossRef Medline

Egger V, Svoboda K, Mainen ZF (2003) Mechanisms of lateral inhibition in the olfactory bulb: Efficiency and modulation of spike-evoked calcium influx into granule cells. J Neurosci 23:7551-7558. Medline

Egger V, Svoboda K, Mainen ZF (2005) Dendrodendritic synaptic signals in olfactory bulb granule cells: Local spine boost and global low-threshold spike. J Neurosci 25:3521-3530. CrossRef Medline

Eyre MD, Antal M, Nusser Z (2008) Distinct deep short-axon cell subtypes of the main olfactory bulb provide novel intrabulbar and extrabulbar GABAergic connections. J Neurosci 28:8217-8229. CrossRef Medline

Eyre MD, Kerti K, Nusser Z (2009) Molecular diversity of deep short-axon cells of the rat main olfactory bulb. Eur J Neurosci 29:1397-1407. CrossRef Medline

Ferreyra Moyano H, Molina JC (1982) Olfactory connections of substantia innominata and nucleus of the horizontal limb of the diagonal band in the rat: An electrophysiological study. Neurosci Lett 34:241-246. CrossRef Medline
Gao Y, Strowbridge BW (2009) Long-term plasticity of excitatory inputs to granule cells in the rat olfactory bulb. Nat Neurosci 12:731-733. CrossRef Medline

Greer CA (1987) Golgi analyses of dendritic organization among denervated olfactory bulb granule cells. J Comp Neurol 257:442-452. CrossRef Medline

Griff ER, Mafhouz M, Perrut A, Chaput MA (2008) Comparison of identified mitral and tufted cells in freely breathing rats: I. Conduction velocity and spontaneous activity. Chem Senses 33:779-792. CrossRef Medline

Haberly LB, Price JL (1977) The axonal projection patterns of the mitral and tufted cells of the olfactory bulb in the rat. Brain Res 129:152-157. CrossRef Medline

Hasselmo ME, Bower JM (1992) Cholinergic suppression specific to intrinsic not afferent fiber synapses in rat piriform (olfactory) cortex. J Neurophysiol 67:1222-1229. Medline

Hoffman WH, Haberly LB (1989) Bursting induces persistent all-or-none EPSPs by an NMDA-dependent process in piriform cortex. J Neurosci 9:206-215. Medline

Hoffman WH, Haberly LB (1991) Bursting-induced epileptiform EPSPs in slices of piriform cortex are generated by deep cells. J Neurosci 11:20212031. Medline

Huynh H, Feldt LS (1976) Estimation of the Box correction for degrees of freedom from sample data in randomized block and split-plot designs. Journal of Educational and Behavioral Statistics 1:69-82. CrossRef

Igarashi KM, Ieki N, An M, Yamaguchi Y, Nagayama S, Kobayakawa K, Kobayakawa R, Tanifuji M, Sakano H, Chen WR, Mori K (2012) Parallel mitral and tufted cell pathways route distinct odor information to different targets in the olfactory cortex. J Neurosci 32:7970-7985. CrossRef Medline

Isaac JT, Nicoll RA, Malenka RC (1995) Evidence for silent synapses: implications for the expression of LTP. Neuron 15:427-434. CrossRef Medline

Isaacson JS, Strowbridge BW (1998) Olfactory reciprocal synapses: dendritic signaling in the CNS. Neuron 20:749-761. CrossRef Medline

Jahr CE, Nicoll RA (1982) An intracellular analysis of dendrodendritic inhibition in the turtle in vitro olfactory bulb. J Physiol 326:213-234. Medline

Laaris N, Puche A, Ennis M (2007) Complementary postsynaptic activity patterns elicited in olfactory bulb by stimulation of mitral/tufted and centrifugal fiber inputs to granule cells. J Neurophysiol 97:296-306. CrossRef Medline

Linster C, Hasselmo ME (2000) Neural activity in the horizontal limb of the diagonal band of broca can be modulated by electrical stimulation of the olfactory bulb and cortex in rats. Neurosci Lett 282:157-160. CrossRef Medline

Linster C, Wyble BP, Hasselmo ME (1999) Electrical stimulation of the horizontal limb of the diagonal band of broca modulates population EPSPs in piriform cortex. J Neurophysiol 81:2737-2742. Medline

López-Mascaraque L, De Carlos JA, Valverde F (1986) Structure of the olfactory bulb of the hedgehog (Erinaceus europaeus): description of cell types in the granular layer. J Comp Neurol 253:135-152. CrossRef Medline

Luo M, Katz LC (2001) Response correlation maps of neurons in the mammalian olfactory bulb. Neuron 32:1165-1179. CrossRef Medline

Luskin MB, Price JL (1983) The topographic organization of associational fibers of the olfactory system in the rat, including centrifugal fibers to the olfactory bulb. J Comp Neurol 216:264-291. CrossRef Medline

Ma TF, Zhao XL, Cai L, Zhang N, Ren SQ, Ji F, Tian T, Lu W (2012) Regulation of spike timing-dependent plasticity of olfactory inputs in mitral cells in the rat olfactory bulb. PLoS One 7:e35001. CrossRef Medline

Macrides F, Schoenfeld TA, Marchand JE, Clancy AN (1985) Evidence for morphologically, neurochemically, and functionally heterogenous classes of mitral and tufted cells in the olfactory bulb. Chemical Senses 10:175202. CrossRef

Manabe H, Kusumoto-Yoshida I, Ota M, Mori K (2011) Olfactory cortex generates synchronized top-down inputs to the olfactory bulb during slow-wave sleep. J Neurosci 31:8123-8133. CrossRef Medline

Mori K (1987) Membrane and synaptic properties of identified neurons in the olfactory bulb. Prog Neurobiol 29:275-320. CrossRef Medline

Mori K, Kishi K, Ojima H (1983) Distribution of dendrites of mitral, displaced mitral, tufted, and granule cells in the rabbit olfactory bulb. J Comp Neurol 219:339-355. CrossRef Medline

Nagayama S, Enerva A, Fletcher ML, Masurkar AV, Igarashi KM, Mori K, 
Chen WR (2010) Differential axonal projection of mitral and tufted cells in the mouse main olfactory system. Front Neural Circuits 4:pii:120. CrossRef Medline

Nakashima M, Mori K, Takagi SF (1978) Centrifugal influence on olfactory bulb activity in the rabbit. Brain Res 154:301-316. CrossRef Medline

Nickell WT, Shipley MT (1988) Neurophysiology of magnocellular forebrain inputs to the olfactory bulb in the rat: Frequency potentiation of field potentials and inhibition of output neurons. J Neurosci 8:44924502. Medline

Orona E, Scott JW, Rainer EC (1983) Different granule cell populations innervate superficial and deep regions of the external plexiform layer in rat olfactory bulb. J Comp Neurol 217:227-237. CrossRef Medline

Orona E, Rainer EC, Scott JW (1984) Dendritic and axonal organization of mitral and tufted cells in the rat olfactory bulb. J Comp Neurol 226:346356. CrossRef Medline

Patil MM, Linster C, Lubenov E, Hasselmo ME (1998) Cholinergic agonist carbachol enables associative long-term potentiation in piriform cortex slices. J Neurophysiol 80:2467-2474. Medline

Paxinos G, Watson C (1997) The rat brain in stereotaxic coordinates, Ed 3. San Diego: Academic.

Phillips CG, Powell TPS, Shepherd GM (1963) Responses of mitral cells to stimulation of the lateral olfactory tract in the rabbit. J Physiol 168:65-88. Medline

Price JL, Powell TP (1970) The mitral and short axon cells of the olfactory bulb. J Cell Sci 7:631-651. Medline

Rall W, Shepherd GM (1968) Theoretical reconstruction of field potentials and dendrodendritic synaptic interactions in olfactory bulb. J Neurophysiol 31:884-915. Medline

Schneider SP, Macrides F (1978) Laminar distributions of internuerons in the main olfactory bulb of the adult hamster. Brain Res Bull 3:73-82. CrossRef Medline

Schneider SP, Scott JW (1983) Orthodromic response properties of rat olfactory bulb mitral and tufted cells correlate with their projection patterns. J Neurophysiol 50:358-378. Medline
Scott JW, Wellis DP, Riggott MJ, Buonviso N (1993) Functional organization of the main olfactory bulb. Microsc Res Tech 24:142-156. CrossRef Medline

Shepherd GM, Chen WR, Greer CA (2004) Olfactory bulb. In: The synaptic organization of the brain, Ed 5 (Shepherd GM, ed). New York: OUP.

Shipley MT, Adamek GD (1984) The connections of the mouse olfactory bulb: a study using orthograde and retrograde transport of wheat germ agglutinin conjugated to horseradish peroxidase. Brain Res Bull 12:669_ 688. CrossRef Medline

Shipley MT, Ennis M (1996) Functional organization of olfactory system. J Neurobiol 30:123-176. Medline

Stripling JS, Galupo MP (2008) Differential potentiation of early and late components evoked in olfactory cortex by stimulation of cortical association fibers. Brain Res 1246:70-79. CrossRef Medline

Stripling JS, Patneau DK (1999) Potentiation of late components in olfactory bulb and piriform cortex requires activation of cortical association fibers. Brain Res 841:27-42. CrossRef Medline

Stripling JS, Patneau DK, Gramlich CA (1988) Selective long-term potentiation in the pyriform cortex. Brain Res 441:281-291. CrossRef Medline

Stripling JS, Patneau DK, Gramlich CA (1991) Characterization and anatomical distribution of selective long-term potentiation in the olfactory forebrain. Brain Res 542:107-122. CrossRef Medline

Struble RG, Walters CP (1982) Light microscopic differentiation of two populations of rat olfactory bulb granule cells. Brain Res 236:237-251. CrossRef Medline

Tseng GF, Haberly LB (1989) Deep neurons in piriform cortex. I. Morphology and synaptically evoked responses including a unique high-amplitude paired shock facilitation. J Neurophysiol 62:369-385. Medline

Wellis DP, Scott JW (1990) Intracellular responses of identified rat olfactory bulb interneurons to electrical and odor stimulation. J Neurophysiol 64: 932-947. Medline

Zimmer LA, Ennis M, Shipley MT (1999) Diagonal band stimulation increases piriform cortex neuronal excitability in vivo. Neuroreport 10 : 2101-2105. CrossRef Medline 